\title{
Testicular histological evaluation and serum testosterone concentrations of bulls after chemical castration with calcium chloride ${ }^{1}$
}

\author{
Lucas F. Pereira², Fernanda G.G. Dias ${ }^{3}$, Marina P. Miguel ${ }^{4}$, Cristiane S. Honsho ${ }^{5}$, \\ Denise C. Tavares ${ }^{6}$, José A.A. Hellú ${ }^{7}$ and Fabiana F. Souza ${ }^{8 *}$
}

\begin{abstract}
Pereira L.F., Dias F.G.G., Miguel M.P., Honsho C.S., Tavares D.C., Hellú J.A.A. \& Souza F.F. 2018. Testicular histological evaluation and serum testosterone concentrations of bulls after chemical castration with calcium chloride. Pesquisa Veterinária Brasileira 38(8):1554-1563. Departamento de Reprodução Animal e Radiografia Veterinária, Faculdade de Medicina Veterinária e Zootecnia, Universidade Estadual Paulista "Júlio de Mesquita Filho", Rua Prof. Dr. Walter Maurício Correa s/n, Cx. Postal 560, Campus de Botucatu, Botucatu, SP 18618-681, Brazil. E-mail: fabiana.f.souza@unesp.br

Orchiectomized bulls have advantages in the meat quality and ease of handling. Chemical castration is an option for surgical castration and the sclerosing agents can be administered into the testicular or epididymis parenchyma. These agents have a lower incidence of complications than surgery, especially when associated with dimethylsulfoxide (DMSO), which has anti-inflammatory action and increases the absorption of other drugs. Thus, this study aimed to evaluate the effect of a single intratesticular injection of calcium chloride solution associated with DMSO for the chemical sterilization of bulls. Twenty-four young adult bulls were utilized, distributed into 3 groups (G20, G30 and G40, n = 8/group), according to the calcium chloride concentration (20,30 and 40\%), in $10 \mathrm{~mL}$ volume. Serum concentrations of testosterone, body weight, testicular volume and ecotexture, clinical signs and behavior and were evaluated for 45 days. Thus, the animals were orchiectomized and testicles were assessed histologically. There were no changes in body weight, decreased serum testosterone concentrations (except G30), signs of scrotal sensitivity or changes in behavior over the period. However, there was significant increase in testicular volume, especially on the 2nd and 3rd day after treatment, with values returning to the value initials at 15 days. Testicular adherence and firm consistency were observed during orchiectomy. Ultrasound examination revealed a loss of integrity of the median raphe, with cavity formation and an alteration of the testicular echotexture. In the histological evaluation, coagulation necrosis of seminiferous tubules and interstitial cells was observed, mainly in the medial portion in all groups. Some animals presented total absence of tubular formations in all the studied groups, being the effects of greater intensity in the G40. Additionally, pronounced edema was noted in all groups,
\end{abstract}

\footnotetext{
${ }^{1}$ Received on August 17, 2017.

Accepted for publication on November 20, 2017.

${ }^{2}$ Medicina Veterinária, Universidade de Franca (Unifran), Av. Dr. Armando de Sales Oliveira 201, Parque Universitário, Franca, SP 14404-600, Brazil. E-mail: lucapereira@gmail.com

${ }^{3}$ Medicina Veterinária, Universidade de Franca (Unifran), Av. Dr. Armando de Sales Oliveira 201, Parque Universitário, Franca, SP 14404-600. E-mail: fernandagosuen@yahoo.com.br

${ }^{4}$ Medicina Veterinária, Universidade Federal de Goiânia (UFG), Rodovia Goiânia Km 8, Campus Samambaia, Goiânia, GO 74001-970, Brazil. E-mail: mapa_mi@hotmail.com

${ }^{5}$ Medicina Veterinária, Universidade de Franca (Unifran), Av. Dr. Armando de Sales Oliveira 201, Parque Universitário, Franca, SP 14404-600. E-mail: crishonsho@yahoo.com.br
}

\footnotetext{
${ }^{6}$ Departamento de Medicina Veterinária Preventiva e Reprodução Animal, Faculdade de Ciências Agrárias e Veterinárias (FCAV), Universidade Estadual Paulista "Júlio de Mesquita Filho" (Unesp), Via de Acesso Prof. Paulo Donato Castelane s/n, Vila Industrial, Jaboticabal, SP 14884-900, Brazil. E-mail: denivet@hotmail.com

${ }^{7}$ Medicina Veterinária, Universidade de Franca (Unifran), Av. Dr. Armando de Sales Oliveira 201, Parque Universitário, Franca, SP 14404-600, Brazil. E-mail: joseabdo@jasaudeanimal.com.br

${ }^{8}$ Departamento de Reprodução Animal e Radiografia Veterinária, Faculdade de Medicina Veterinária e Zootecnia (FMZV), Universidade Estadual Paulista "Júlio de Mesquita Filho" (Unesp), Rua Prof. Dr. Walter Maurício Correa s/n, Campus de Botucatu, Cx. Postal 560, Botucatu, SP 18618-681. *Corresponding author: fabiana.f.souza@unesp.br
} 
especially in G40. Inflammatory infiltrate, fibroplasia and neovascularization were found to be predominantly discrete. Based on the conditions used in this study, we conclude that calcium chloride associated with DMSO can be used as a method of chemical sterilization in bovines.

INDEX TERMS: Testicle, histology, serum testosterone, bulls, chemical castration, calcium chloride, dimethyl sulfoxide, sclerosing agent, seminiferous tubule, testosterone.

RESUMO.- [Avaliação histológica e das concentrações séricas de testosterona de touros após a castração química com cloreto de cálcio.] Bovinos orquiectomizados apresentam vantagens na qualidade da carne e facilidade no manejo. A quimioesterilização é uma opção à castração cirúrgica e os agentes esclerosantes podem ser administrados no parênquima testicular ou epidídimo. Estes produtos possuem menor incidência de complicações, comparados a cirurgia, especialmente quando associados ao dimetilsulfóxido (DMSO), que apresenta ação anti-inflamatória e aumenta a absorção de outros fármacos. Assim, este estudo teve como objetivo avaliar o efeito de uma única injeção intratesticular de solução de cloreto de cálcio associado com $0,5 \%$ de DMSO para a esterilização química de bovinos. Vinte e quatro touros adultos jovens foram utilizados, distribuídos em 3 grupos (G20, G30 e G40, n = 8/grupo) de acordo com a concentração de cloreto de cálcio (20, 30 e 40\%), em um volume de $10 \mathrm{~mL}$. Foram avaliadas as concentrações séricas de testosterona, peso corporal, volume e ecotextura testicular, sinais clínicos e comportamento por 45 dias. A seguir, os animais foram submetidos à orquiectomia e os testículos avaliados histologicamente. Não foram observadas alterações do peso corporal, diminuição das concentrações de testosterona sérica (exceto no G30), sinais de sensibilidade escrotal ou alterações no comportamento no período avaliado. Porém, houve aumento significativo do volume testicular, especialmente nos $2^{\circ}$ e $3^{\circ}$ dia após o tratamento, com valores retornando aos iniciais aos 15 dias. Aderência e consistência firme dos testículos foram achados observados durante a orquiectomia. 0 exame ultrassonográfico revelou perda de integridade da rafe mediana, com formação de cavidades e alteração da ecotextura testicular. Na avaliação histológica, verificou-se necrose de coagulação de túbulos seminíferos e células intersticiais acentuada, principalmente, na porção medial em todos os grupos, sendo que em alguns animais havia ausência total das formações tubulares em todos os grupos estudados, sendo os efeitos de maior intensidade no G40. Além disso, edema foi acentuado em todos os grupos, principalmente em G40. Infiltrado inflamatório, fibroplasia e neovascularização foram achados predominantemente discretos. Com base nas condições utilizadas neste estudo, conclui-se que o cloreto de cálcio associado com o DMSO pode ser utilizado como um método de esterilização química em bovinos.

TERMOS DE INDEXAÇÃO: Histologia, concentrações séricas, testosterona, touros, castração química, cloreto de cálcio, agente esclerosante, dimetil sulfóxido, túbulo seminífero.

\section{INTRODUCTION}

In the livestock industry, the sterilization of males is indicated to avoid unwanted mating and improve the ease of handling (Almeida et al. 2010). Moreover, it can be used as a strategy for improving the meat quality to reach the standards demanded by the market, which are related to improvements in animal housing and greater consumer acceptance (Rodrigues et al. 2003, Prado et al. 2004, Santos 2005, Angelo et al. 2010).

Discomfort, pain and stress may be associated with lack of technical knowledge of the surgeon. These non-adherent postoperative care and time-related causes increase the chance of complications, which makes a procedure considered simple in traumatic and painful surgery (Andrade 2002). In bovines, the most commonly used sterilization method is the orchiectomy, but the use of inadequate materials, improper environments, antisepsis failure, a lack of technical knowledge, inexperience and a lack of analgesia are the main factors that make this a traumatic procedure (Hedlund 2005). In addition, local bleeding (Silva et al. 2009, Almeida et al. 2010), myiasis (Andrade 2002), edema (Turner \& McIlwaith 2002, Silva et al. 2006) and secondary infections are complications that can occur during and after the surgery (Alves et al. 2007, Almeida et al. 2010).

Another form of sterilization has been described that is based on the intratesticular administration of agents sclerosing such as ferric chloride, ferrous sulfate, danazol, zinc, glycerol, glucose, physiological solution, lactic acid (Soto et al. 2007), formalin, potassium permanganate (Canpolat et al. 2006), cadmium chloride, (Jana \& Samanta 2007) and calcium chloride (Mitra \& Samanta 2000, Jana et al. 2005, Canpolat et al. 2006, Jana \& Samanta 2007) are able to cause irreparable tissue damage and a loss of testicular function (Immegart \& Threlfall 2000, Jana \& Samanta 2007, Muller et al. 2009a, $2009 \mathrm{~b}$ ). The administration of testicular sclerosing agents has been studied in various animals, such as monkeys (Kar et al. 1965), rodents (Habenicht et al. 1990, Santamaria et al. 1995), dogs (Pineda et al. 1977, Barnett 1985, Fahim et al. 1993, Wang 2002, Oliveira 2007, Muller et al. 2010,), cats (Pineda \& Dooley 1984), sheep (Pineda et al. 1977), goats (Jana et al. 2005), bovine (Andrade-Neto et al. 2014, Cavalieri et al. 2015, Oliveira etal. 2017) and humans (Wong 2001, Carvalho 2010), to achieve chemical sterilization.

After injury, fibrous tissue proliferation occurs within the testicular parenchyma, and a decrease in spermatogenesis and a reduction in androgen levels can be observed in some species (Oliveira 2007, Andrade-Neto et al. 2014).

Calcium chloride has been described for use as a sterilizing agent in rodents, dogs, cats, goats and bulls (Mitra \& Samanta 2000, Jana et al. 2005, Canpolat et al. 2006, Jana \& Samanta 2007, Jana \& Samanta 2011). The results were satisfactory in the majority of these species, but Canpolat et al. (2006) found that it was not successful in sterilizing bulls, while Mitra \& Samanta (2001) reported a reduction in serum testosterone levels.

The association of DMSO with sclerosing agent (zinc gluconate and clorhexidine digluconate, respectively) was described in dogs and the chemical castration was able to induce subfertility and infertility in the treated animals 
with intratesticular injections (Vannucchi et al. 2015) or epididymis tail (Navarrete 1997). Moreover, DMSO has some pharmacological actions, especially analgesic, anti-inflammatory and increases the diffusion of other drugs throughout tissues, which contribute to the chemical castration effect (Pearson et al. 1980, Penasso 2005, Vannucchi et al. 2015).

Because of the limited number of reports in the literature about alternative, atraumatic and less invasive techniques to achieve sterilization in bulls, the present study aimed to evaluate the clinical effects and alterations in spermatogenesis and serum testosterone concentrations in bulls as a result of receiving of a single application of intratesticular calcium chloride at three different concentrations $(20,30$ or $40 \%)$ associated with $0.5 \%$ DMSO.

\section{MATERIALS AND METHODS}

The study was conducted in accordance with the ethical guidelines recommended by the National Council for the Control of Animal Experimentation and the College of Animal Experimentation and was approved by the Institution's Animal Care and Experimentation Ethics Committee (Protocol Number 027/2010).

Twenty-four Nelore crossbred bulls were used $(n=24)$. They had an initial weight between 300 and $400 \mathrm{~kg}$, were 2.5 to 3.5 years old, and had been wormed and vaccinated as legally required.

The absence of changes in the testes, epididymis, scrotal pouch, spermatic cord, penis and foreskin, as well as no alterations to the ultrasound examination (Hafez \& Hafez 2004), were used the criteria used to include the animals in this study.

The animals were kept at a population density of 2 animal unit/ha and were fed Brachiaria decumbens, water and mineral supplementation ad libitum.

The bulls were randomly separated into three groups of eight animals each based on the concentration of the aqueous calcium chloride solutions administered: G20 (20\% calcium chloride), G30 (30\% calcium chloride) and G40 (40\% calcium chloride). All preparations contained $0.5 \%$ dimethyl sulfoxide (DMSO) and were at a neutral $\mathrm{pH}$.

After the mechanical wrapping of the animal and scrotal antisepsis, the spermatic cords were anesthetized with $200 \mathrm{mg}$ lidocaine hydrochloride (Xylestesin cloridrato de lidocaína 2\%, Cristália, Itapira/SP, Brazil) (Andrade 2002). The calcium chloride was administered with $10 \mathrm{~mL}$ syringes and $30 \mathrm{x} 8 \mathrm{~mm}$ needles, and injections were made into the medial testicular region in a craniocaudal direction. The volume administered in each testis $(10 \mathrm{~mL})$ was the same for all groups and was based on the findings of Canpolat et al. (2006).

Blood samples were collected from all animals to determine serum total testosterone levels by chemiluminescence. The samples were collected four days before (D-4) the intratesticular application of calcium chloride and at 7 (D7), 15 (D15) and 45 (D45) days after treatment. Samples were collected at the same time of day and from animals in the same sequence on all sampling days.

During the experimental period, the animals were inspected daily by the same evaluator to check for behavioral changes and lameness.

On three consecutive days after calcium chloride administration, body temperature, heart rate and respiratory frequency were measured.

The testicular sensitivity was assessed based on the presence or absence of pain in response to touch and manual compression, and tests were considered positive in animals that expressed hindlimb agitation. Moreover, the consistency (fibroelastic, flaccid or firm), mobility (free scrotal movement or adhered), and degrees of edema and scrotal dermatitis were assessed. These assessments were made in the first three days (D1 to D3) after calcium chloride administration and at D7, D15 and D45. All animals were weighed at the same times on an electronic balance.

Testicular volume was calculated using the values of testicular length, height and width (Bailey et al. 1998) as measured with a caliper four days before (D-4) and on the first two days (D1 and D2), D15 and D45 after the administration of calcium chloride.

Testicular echotexture (Mindray DP 2200, Shenzhen, China) was evaluated four days before (D-4) and 15 (D15) and 45 (D45) days after the administration of calcium chloride.

Orchiectomy was performed 45 days after the administration of calcium chloride, using a conventional surgical technique under regional (at the spermatic cord) and local (at the incision) anesthesia and tranquilization.

After orchiectomy, the 48 testes were washed in $0.9 \%$ saline solution and immediately sectioned into three slices (proximal, middle and distal), which were used for histological preparation.

The fragments were fixed in $10 \%$ buffered formalin, dehydrated in increasing concentrations of ethanol (70\%, 80\%, 90\% and absolute), cleared in xylene and embedded in paraffin (Luna 1968). The blocks were sectioned on a rotary microtome (Leica RM2125RT, Leica Biosystem, São Paulo/SP) at a 4-mm thickness and stained with hematoxylin-eosin (HE) (Sheehan \& Hrapchak 1980). The slides were evaluated using light microscope (Nikon Eclipse E200, Sendai, Miyagi, Japan).

Histological evaluation was performed in both testicles (right and left) in three testicular portions (proximal, medial and distal). Testicular tissue (parenchymal and interstitial space) was evaluated for necrosis, edema, inflammatory infiltrates, calcification, fibroblast proliferation (fibroplasia) and neovascularization. Injuries were evaluated semi-quantitatively and an intensity score was determined as follows: 0 (no injury), 1 (mild injury, up to 30\%), 2 (moderate injury, 30 to $60 \%$ ), and 3 (pronounced, over $60 \%$ ).

Results were presented as the mean with a standard error. Kolmogorov-Smirnov tests were used to check the data for normal distributions. Differences at each time period for each group were tested for via a one-way repeated measures analysis of variance for normally distributed variables (body weight, respiratory frequency, body temperature, testicular volume and testosterone concentration) or a Friedman repeated measures analysis of variance based on ranks for variables without a normal distribution (heart rate). Differences

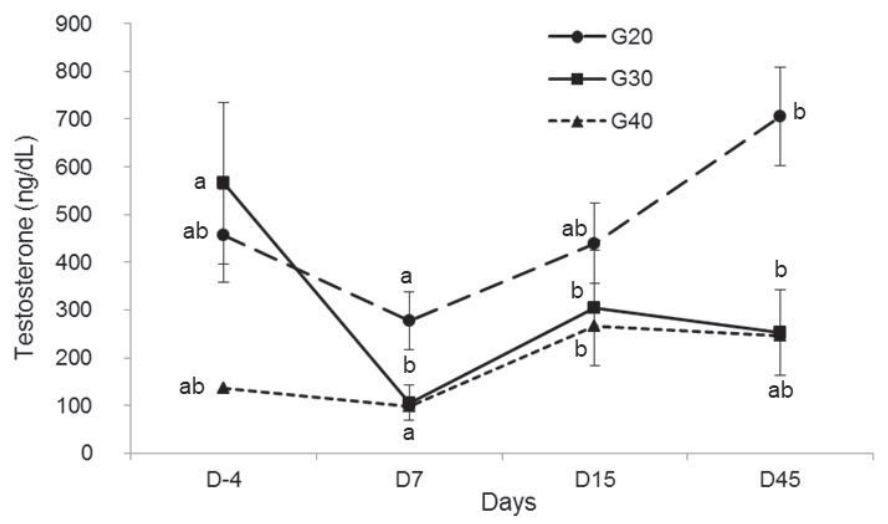

Fig.1. Mean \pm standard error of serum testosterone concentrations from bulls subjected to chemical castration with calcium chloride. Different letters indicate statistically significant differences in each moment on group at $\mathrm{p}<0.05$. 
between the groups at each time period were verified using a one-way analysis of variance (body weight, body temperature, heart rate, testicular volume) and a Kruskal Wallis test (respiratory frequency, testosterone concentration). In all cases, the Student-Newman-Keuls multiple comparison procedure was used. Analysis of the clinical assessments, ultrasound examinations and histological analyses were performed based on frequency descriptions. All analyses were performed using SigmaStat for Windows Version 11.0. Significance was set at $\mathrm{p} \leq 0.05$.

\section{RESULTS}

In the present study, there were no changes in the behavioral parameters evaluated. The heart rate (mean \pm standard error of all groups, D1: 77.2 \pm 4.0 beats. min $^{-1}$, D2: $77.9 \pm 5.2$ beats. min $^{-1}$; D3: $68.3 \pm 3.3$ beats. min $^{-1}$ ), respiratory frequency (mean \pm standard error of all groups D1: $31.2 \pm 1.5$ breaths.min ${ }^{-1}$; D2: $35.4 \pm 1.5$ breaths. min $^{-1}$; $31.2 \pm 2.1$ breaths. $\mathrm{min}^{-1}$ ) and body temperature (mean \pm standard error of all groups, D1: $38.8 \pm 0.1^{\circ} \mathrm{C}$; D2: $39.0 \pm 0.1^{\circ} \mathrm{C}$; D3: $38.8 \pm 0.1^{\circ} \mathrm{C}$ ) did not change during the three-day period after calcium chloride administration.

There were no lesions on the scrotal skin following calcium chloride administration and no sensitivity to touch or manual compression of the testicles was detected.

Testicular and scrotal edema was pronounced until the 7 th day after the administration of the calcium chloride solution. Table 1 shows that edema gradually decreased and was not present on the 15 th day (D15) in G20 and at 45 days (D45) in G30. However, $12.5 \%$ of animals in G40 still showed testicular and scrotal edema after 45 days.

Physical examination demonstrated a hardening of the testicle that was observed from D7 to D45, especially in G30 and G40 (Table 2).

During surgery we noted a thickening and adhesion of the testicular tunics and adjacent tissues. The spermatic cord showed an increased thickness and consistency. A progressive decrease in adherence until D45 was observed in all groups, especially in G40 (Table 3).

There was a decrease in body weight $(\mathrm{p}<0.05)$ by D7 when compared to weights on D-4, with a return to initial body weights occurring by D15, and a gain in body weight was observed on D45 in G30 and G40. In G20, there was no body weight gain by D45.

Serum concentrations of testosterone (Fig.1) did not change over most of the periods except for a significant increase in G20 on D45 and in G30 on D7, which returned to pre-application concentrations by $\mathrm{D} 45$.

Testicular volumes were increased after calcium chloride injections $(p<0.05)$ in all groups until D2, except in G20, and returned to pre-injection volumes by D45 (Fig.2).

Ultrasound examinations pre-administration identified homogenous testicular parenchyma with a clear identification of testicular raphae. From D15 to D45, cystic formations, discontinuous median raphae and a wide distribution of hyperechoic spots in the testicular parenchyma (fibrosis or calcification) were observed (Fig.3).

The main histological finding indicative of reduction or loss of testicular function on 45 days after calcium chloride application, using different concentrations was the coagulative necrosis (Fig. 4A and E) of seminiferous tubules and interstitial cells, verified by eosinophilia, absence of nucleus in the
Table 1. Percentage (\%) of cattle with testicular/scrotal edema after chemical castration at different concentrations

\begin{tabular}{clll}
\hline Day & \multicolumn{1}{c}{ G20 } & \multicolumn{1}{c}{ G30 } & \multicolumn{1}{c}{ G40 } \\
\hline D1 & $7(87.5)$ & $8(100.0)$ & $8(100.0)$ \\
D2 & $8(100.0)$ & $7(87.5)$ & $7(87.5)$ \\
D3 & $7(87.5)$ & $7(87.5)$ & $7(87.5)$ \\
D7 & $6(75.0)$ & $7(87.5)$ & $6(75.0)$ \\
D15 & $0(0)$ & $2(25.0)$ & $5(62.5)$ \\
D45 & $0(0)$ & $0(0)$ & $1(12.5)$
\end{tabular}

Table 2. Percentage (\%) of rigid tests of bovines submitted to chemical castration in different concentrations

\begin{tabular}{clll}
\hline Day & G20 & \multicolumn{1}{c}{ G30 } & \multicolumn{1}{c}{ G40 } \\
\hline D1 & $8(100.0)$ & $8(100.0)$ & $7(87.5)$ \\
D2 & $8(100.0)$ & $8(100.0)$ & $8(100.0)$ \\
D3 & $7(87.5)$ & $8(100.0)$ & $8(100.0)$ \\
D7 & $5(62.5)$ & $7(87.5)$ & $6(75.0)$ \\
D15 & $3(37.5)$ & $6(75.0)$ & $7(87.5)$ \\
D45 & $3(37.5)$ & $6(75.0)$ & $3(37.5)$
\end{tabular}

Table 3. Percentage (\%) of testicular adhesion to the adjacent tissues of bovines submitted to chemical castration at different concentrations

\begin{tabular}{cccc}
\hline Day & G20 & \multicolumn{1}{c}{ G30 } & G40 \\
\hline D1 & $3(37.5)$ & $3(37.5)$ & $5(62.5)$ \\
D2 & $3(37.5)$ & $5(62.5)$ & $8(100.0)$ \\
D3 & $5(62.5)$ & $8(100.0)$ & $8(100.0)$ \\
D7 & $4(50.0)$ & $5(62.5)$ & $6(75.0)$ \\
D15 & $2(25.0)$ & $6(75.0)$ & $7(87.5)$ \\
D45 & $1(12.5)$ & $4(50.0)$ & $5(62.5)$
\end{tabular}

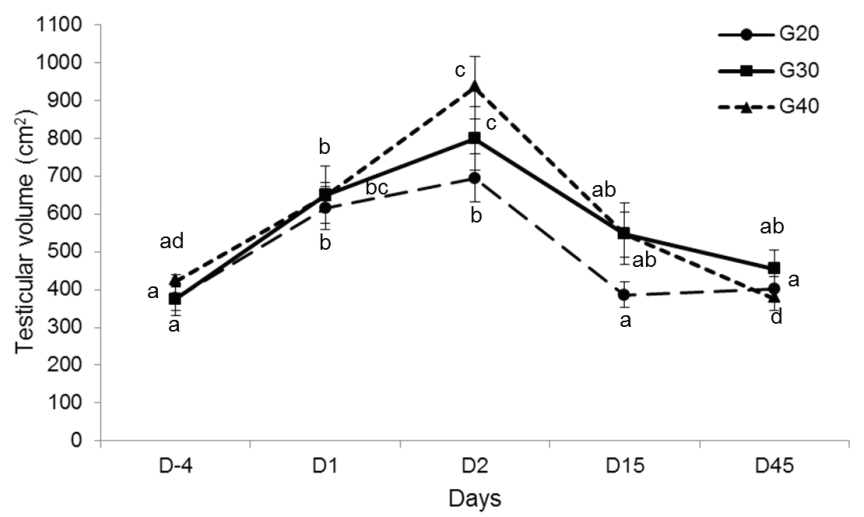

Fig.2. Mean \pm standard error of testicular volume from bulls subjected to chemical castration with calcium chloride. Different letters indicate statistically significant differences in each moment on group at $\mathrm{p}<0.05$.

germinative cells and absence of cells within seminiferous tubules (Fig.4B and C). Areas with liquefaction feature (Fig.4D) were also found. In all groups and all testicular portions these injuries were predominant in most of the assessed tissue. In all groups, the medial testicular portion presented over $60 \%$ of 


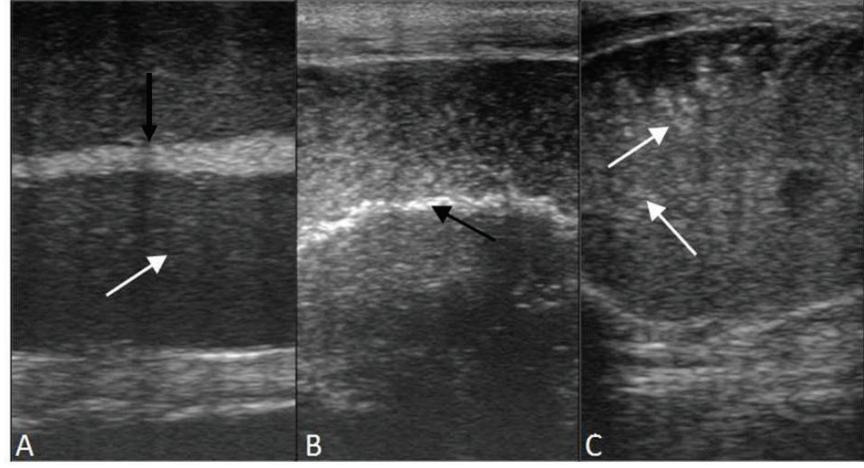

Fig.3. Ultrasound exam of testicle from bulls. (A) Pre-administration of calcium chloride; the median raphe (black arrow) and testicular parenchyma integrity (white arrow). (B) Fifteen days after calcium chloride administration; abnormal median raphe (black arrow) and hiperecoic testicular parenchyma. (C) Forty five days after calcium chloride administration; absence of median raphe, calcified foci (white arrows) and cavitations (hipoecoic tissue). injured tissue (Table 4). Tissue necrosis was observed in the proximal and distal testicular areas near the medial section. In these portions, areas with intact tissue were found, mainly in G20. In all treatments, the seminiferous tubules remained intact near the tunica albuginea, to the greatest extent in G20, but in all groups, the spermatozoa in the tubular lumen were absent.

Discrete to absent inflammatory infiltration (Fig.4F), predominantly polymorphonuclear, with discrete mononuclear infiltration, and fibroplasia were observed around the seminiferous tubules more frequently in the distal, medial and proximal testicular regions in all treatments. Edema was pronounced in G40, and in G20 (Fig.4A) and G30, it ranged from mild to moderate in all tissue portions. In all groups, there was predominantly discrete neovascularization, but in the proximal testicular portion of G20 there was moderate to severe neovascularization in most samples. In addition, discrete areas of calcification were found in all groups,

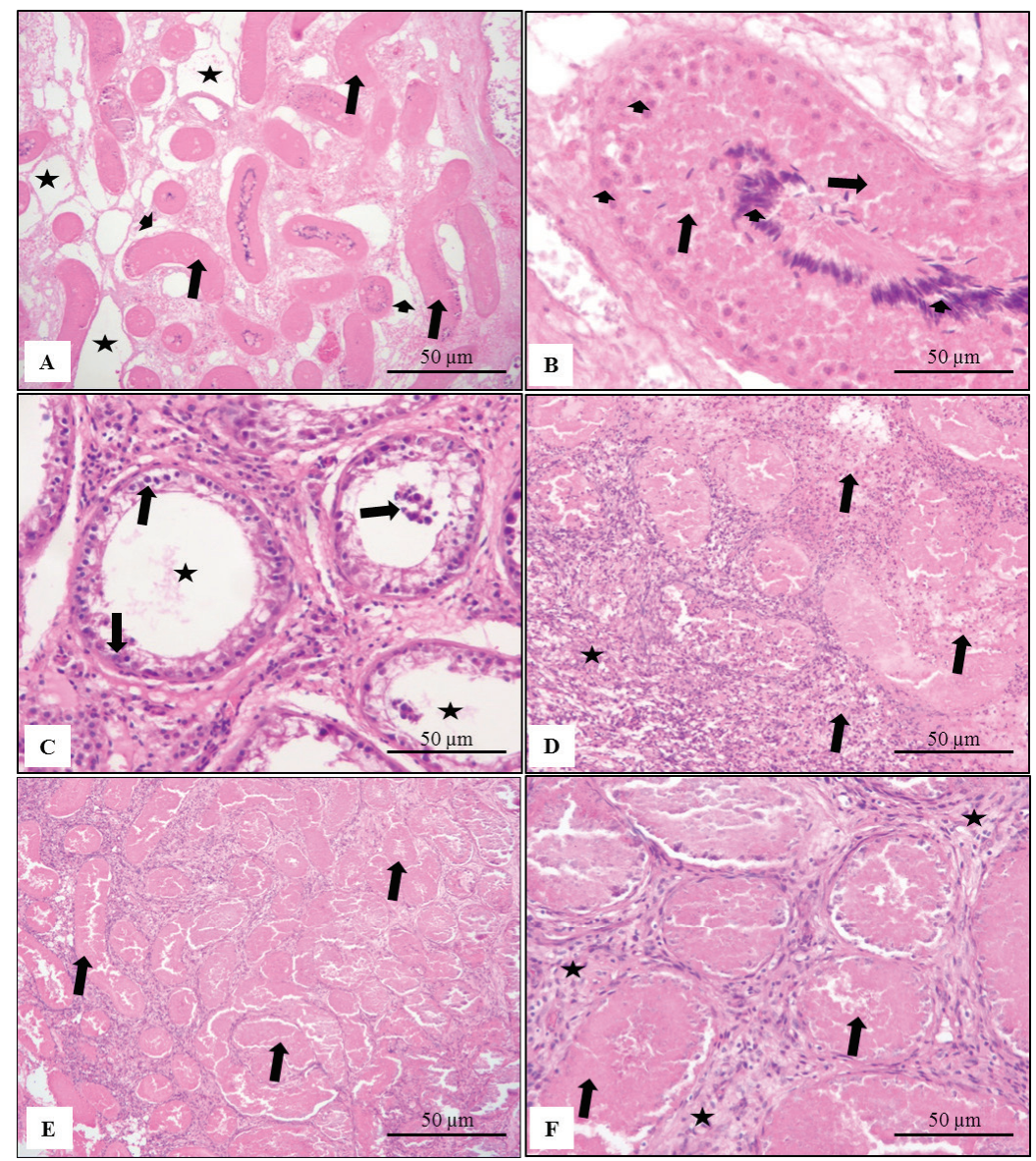

Fig.4. Histological characteristic of the bovine testicles/epididymides after chemical castration with 20 (G20), 30 (G30) and 40\% (G40) calcium chloride associated with 0.5\% DMSO. (A) Proximal portion of testicle, G20. Difuse and pronounced coagulative necrosis (arrows) in seminiferous tubules, multifocal absence of seminiferous tubules (stars), moderate intertubular edema (arrow head). HE, obj.50x. (B) Distal portion of testicle, G20. Death (karyolysis) of spermatogenic cells (arrows), nuclear basophilia in the cells, with alive features (arrow head). HE, obj.40x. (C) Proximal portion of epididymis, G20. Vacuolated, necrotic and desquamated epithelial cells (arrows) and absence of spermatozoa within the lumen of the epididymal tubule (stars). HE, obj.20x. (D) Distal portion of testicle, G30. Liquefied necrosis (arrows) and pronounced neutrophilic inflammatory infiltrates (star). HE, obj.10x. (E) Distal portion of testicle, G40. Difuse and pronounced coagulative necrosis (arrows) in seminiferous tubules. HE, obj.50x. (F) Distal portion of testicle, G40. Death (karyolysis) of spermatogenic cells (arrows), mild mixed inflammatory infiltrates, mild intertubular fibrosis (star). HE, obj.20x. 


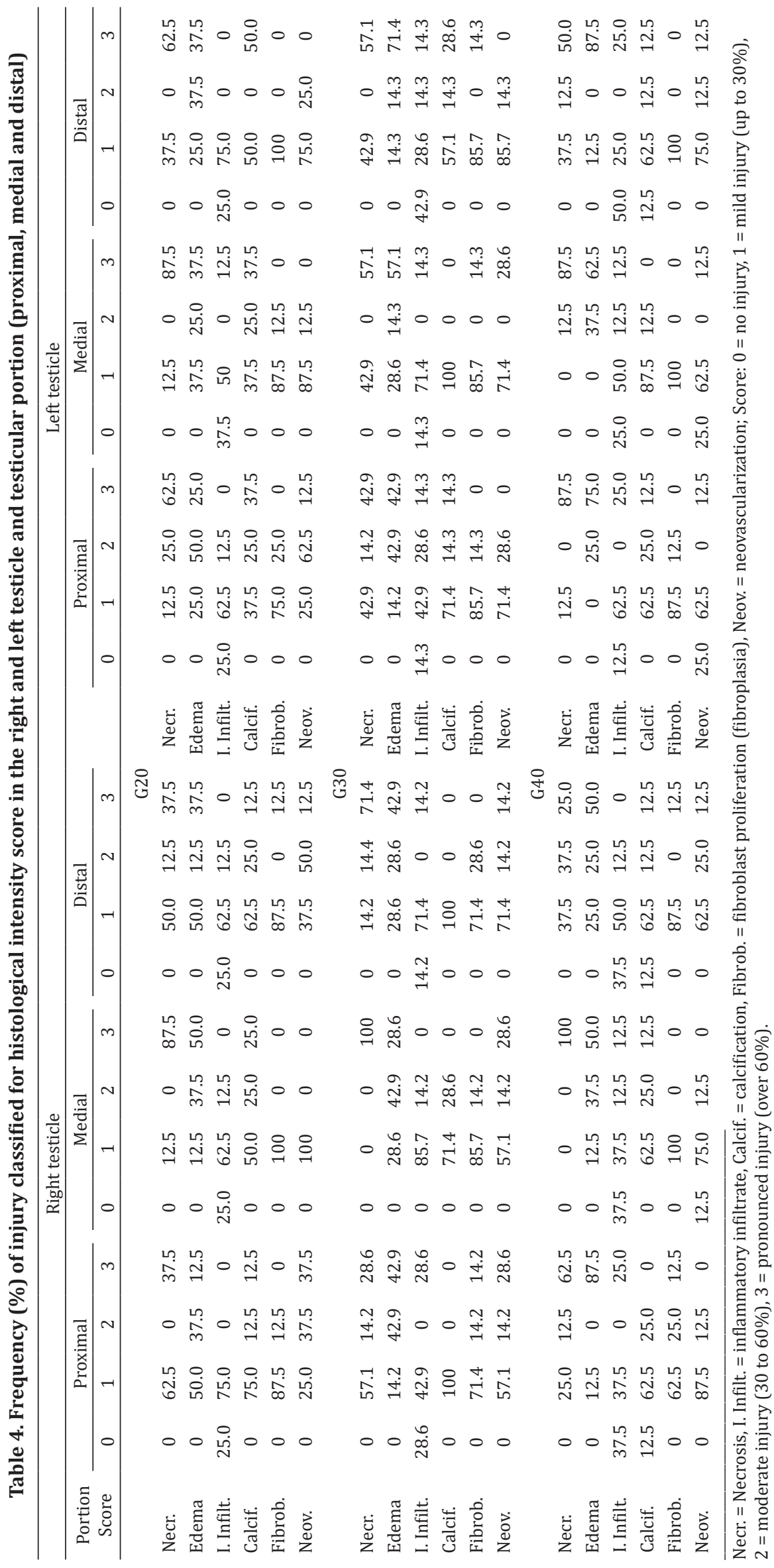


particularly in the interior of seminiferous tubules and in basement membrane.

\section{DISCUSSION AND CONCLUSION}

This study seems to be the first to evaluate the association between calcium chloride and DMSO for the chemical castration of bulls, considering aspects such as pain, macroscopic and microscopic changes and testosterone concentrations. The outcome showed that the chemical castration was able to induce coagulation and liquefied necrosis of tissue components with no pain on palpation, becoming an alternative method for bull castration.

An initial study on chemical sterilization with calcium chloride in bulls used $25-30 \%$ solutions in ethanol and injections near the epididymal head. Dosages ranged from 1.0 to $1.5 \mathrm{~mL} / 45 \mathrm{~kg}$ body weight. In this study, testicular atrophy occurred between 1 to 3 months after treatment (Koger 1977). In another study, the author describes two case reports in which the same solution was used and where discomfort some hours after injection was observed (Koger 1978). In our study, the intratesticular application of calcium chloride was chosen instead of intraepididymal and intraductal applications (Goldsmith et al. 1985) due to the ease of injecting the fluid at this site. The volume $(10 \mathrm{~mL})$ and concentrations of the calcium chloride solutions injected into each testis were based on the findings of Canpolat et al. (2006). These researchers tested chemical castration with calcium chloride in bulls using a $30 \%$ solution but showed unsatisfactory results. In view of this, the present study evaluated a lower (20\%) and higher (40\%) concentration to test the efficacy and safety of these solutions when used with an intratesticular route in bulls. In our work, we chose to use different concentrations and to maintain a fixed volume, unlike the study by Jana \& Samanta (2006), which used different concentrations of calcium chloride based on each $100 \mathrm{~g}$ of testicle/body weight (kg). If we had used these calculations, the volumes of the intratesticular injections would have been too large, making their application impossible.

Clinical evaluations of the bulls after calcium chloride administration showed no changes related to vital parameters, indicating no adverse reactions to the sterilizing agent. Similar results were also described by Jana \& Samanta (2007) using calcium chloride in goats for chemical castration.

Body weights were found to be decreased at the first examination after the application of the solution, possibly related to pain-induced decreases in feeding, although there were no signs of pain observed in response to testicular palpation. We suggest that the loss of weight in this period may also have been related to stress during the examinations, which was more pronounced in the first 7 days. Furthermore, the study was conducted during a period of limited pasture availability due to reduced rainfall, and in an extensive farming system, which may have also contributed to the decreased weight gain. There was no change in appetite or decreases in body weight by the end of the experiment. Martins et al. (2011) also mentioned low gain weight and no expressions of pain in response to testicular palpation in buffaloes chemically castrated with $30 \%(\mathrm{w} / \mathrm{v})$ calcium chloride at a dose of $1 \mathrm{~mL} / 100 \mathrm{~kg}$ of body weight. In addition, Pate et al. (1970) reported the same condition in bulls undergoing intratesticular injections of cadmium chloride, although these authors also mentioned a decrease in appetite and weight reduction correlated to the intense inflammatory process that occurred in the testis in the initial days post-injection. However, Jana \& Samanta (2007) did not mention a decrease in food consumption when using calcium chloride for the chemical castration of dogs.

During orchiectomy, the presence of fibrosis, adherence, and a thickening of the testicular tunic and adjacent tissues were verified in most bulls. In a study on rodents, Jana \& Samanta (2006) reported that calcium chloride, when applied intratesticularly, also caused visible damage to the tail of the epididymis, confirming the findings of the present study, in which calcium chloride injections promoted testicular and epididymal atrophy.

Testis adhesion to adjacent tissue was noticeable in all animals and has also been described by Lewis \& Garcia (1984) in primates after the use of different sclerosing agents (glycerol formalin and quinacrine methyl-cyanoacrylate in a saline solution). In cats, Pineda \& Dooley (1984) described this change between the scrotum and the tail of the epididymis after the intraepididymal administration of $4.5 \%$ chlorhexidine gluconate.

In this study, adhesion gradually decreased over the assessment period but was still evident in all groups at D45. It is likely that calcium chloride concentration is related to the intensity of adhesion because at the end of the study, the animals in G40 showed more severe adherence than those in G30, which also showed greater adhesion than those in G20.

Tunica albuginea thickening and areas of testicular disintegration were observed in most samples, particularly in G40. Circumscribed areas, that were yellowish, friable, and isolated or associated with gray and opaque areas were also observed, which were interpreted as indicating tissue necrosis (Cheville 1994, Santos 1978). Cavitated areas, suggesting cysts or abscesses, were noted in some animals, which similar to the changes described by Canpolat et al. (2006) after the chemical sterilization of bulls.

All animals showed increased testicular consistency upon palpation on the second day post-injection. The frequency of this change was greater in the G30 and G40 animals; however, these changes remained in all groups until the end of the study. These findings corroborate those reported by Plant et al. (1979) with the use of a formaldehyde solution in ethanol injected into the epididymides of rams.

Considering all groups, there were individual variations in testosterone concentrations, which were associated with individual differences in daily hormone metabolism (Jana \& Samanta 2006, Oliveira 2007), even though the samples were collected at the same time and from animals in the same order.

Different studies have evaluated serum testosterone concentrations after chemical sterilization, and most have observed non-significant decreases (Neilson et al. 1997, Canpolat et al. 2006, Muller et al. 2010). Despite this, decreased testosterone concentrations have been mentioned in goats (Jana et al. 2005) and dogs (Jana \& Samanta 2007), with the use of calcium chloride, and in bulls (Canpolat et al. 2006), with the used of ethanol, when intratesticularly administered. However, only the study by Jana et al. (2005) described a loss of libido.

Changes in reproductive behavior were not evaluated in the present study; however, castrated males have been shown to 
present no changes in behavior (Neilson et al. 1997), and it is necessary to wait a minimum of 6 to 12 months after hormonal disruption to observe changes in libido (Munson et al. 2004, Muller et al. 2010), which did not occur in the present study because the animals were evaluated only up to 45 days after the application of calcium chloride. Furthermore, Fahim et al. (1993) and Soto et al. (2007) reported that most chemosterilants that have been tested are not efficient in decreasing testosterone concentrations and/or libido. Recently, Vanderstichel et al. (2015) also described no change in plasma testosterone in dogs chemically sterilized with calcium chloride. These authors mentioned that only $30 \%$ of the dogs presented a reduction of testosterone 6 months after treatment.

In this study, an increase in testicular volume was observed in the initial days after the application of calcium chloride. This increase was followed by a reduction in volume back to the initial values. Nevertheless, tissue edema, as evidenced by histological observations, persisted until 45 days in all groups. The intensity of edema was related to the concentration of calcium chloride injected, with edema more evident in G40 than in the other groups. This finding is explained by an increased inflammatory reaction triggered by the body's response to injury (Thomson 1983). Despite this, the inflammatory response was local, occurred quickly and was without progression because other related changes (e.g., changes in body temperature) were not observed. This fact may be associated with the use of DMSO in the formulation or with the lower inflammatory response stimulated by calcium chloride, as Jana \& Samanta (2007) have previously mentioned. However, these last authors did not use DMSO in their formulation of the calcium chloride solutions used in rats, and they also did not report any systemic inflammatory reactions. In addition, no painful clinical signs were manifested by bulls during evaluations for sensitivity to touch and manual compression of the testes, corroborating findings in goats undergoing chemical castration with calcium chloride, in which no changes in serum cortisol were found (Jana et al. 2005).

These findings may also be related to the use of DMSO in the formulation because of its anti-inflammatory and analgesic effects (Penasso 2005, Guimarães et al. 2010). Moreover, the fact that testicular nerve endings are located in the scrotum may be another important factor contributing to decrease sensitivity (Setchell et al. 1994) because no scrotal lesions were observed. In addition, the neutral pH of the calcium chloride solution resembles that of the testicular constituents (Fahim et al. 1993), so it may be that there was no change in the scrotal skin. In contrast, Oliveira (2007) and Wang (2002) described irritation, ulcers and/or dermatitis in the scrotum of dogs, which were associated with poor animal restraint during the procedure, incorrect application of the treatment, and the physical and environmental conditions of the kennels and the canine behavior of scrotal licking.

During testicular ultrasound examinations irregularities in the median raphe and hyperechoic parenchymal points were observed. We also observed cavitated areas (most evident in G40) with anechoic content at 45 days, suggesting the presence of cysts or abscesses (Nyland \& Mattoon 2001).

Histologically, coagulation necrosis was observed in all testicles. It was markedly diffuse and was present mainly in the medial region. This finding was more evident in the seminiferous tubules, which has also been observed in other studies (Jana et al. 2005, Canpolat et al. 2006, Jana \& Samanta 2007). The intensity of necrosis was dependent on the calcium chloride concentration, and practically all testicular tissue from G40 was affected. Effects of calcium chloride on testicular tissue may be related to the concentration and volume of the solution injected, as Martins et al. (2011) reported that they did not obtain complete testicular fibrosis using a 30\% calcium chloride solution in buffalo. In the current study, we tried to develop a solution with a higher percentage of calcium chloride to decrease the volume injected. However, higher concentrations of the salt in solution allow for precipitation, making the solution unusable.

The mechanism of action for the effects of calcium chloride has not been elucidated, but it is assumed that it causes anoxia or hypoxia in testicular tissue. This process favors the presence of polyunsaturated fatty acids, which are capable react with free radicals (Guimarães et al. 2010), promoting peroxidation, which acts on mitochondrial cellular membrane, altering their permeability (McLachlan 2000). This process triggers cellular changes (Aydos et al. 1998) and inhibits spermatogenesis (Jana et al. 2005). Although testicular tissue contains antioxidants (Guimarães et al. 2010), following severe injuries, the protective mechanisms against free radicals are insufficient. These findings were confirmed by Jana \& Samanta (2007), who found high concentrations of an enzyme responsible for eliminating free radicals in dogs after chemical sterilization with calcium chloride. This explains the hydropic degeneration in the cells of the seminiferous tubules found in our study. Nevertheless, intact seminiferous tubules were observed in the region near the albuginea tunic, especially in G20 and G30, which indicates that higher concentrations of the calcium chloride were more toxic to tissue.

Calcification foci were found in the seminiferous tubules, especially in the periphery of the testis. According to Santos (1986) and Thomson (1983), this calcification is classified as dystrophic due to calcium salt penetration in necrotic testicular cells.

Polymorphonuclear inflammatory infiltrates were observed in the histopathological examinations in all groups. This change indicates the progression of tissue liquefaction, which corresponds to areas of cavitation observed upon gross examination (Santos 1986, Cheville 1994). The disruption of cellular integrity is another mechanism of action attributed to the calcium chloride (Jana \& Samanta 2007). Moreover, the action of this product may also be related to hematotesticular barrier disruption, which is responsible for maintaining the adluminal environment (Hafez \& Hafez 2004). The application of sclerosing agents into the testis breaks down hematotesticular barrier, allowing the extravasation of stem cells into the interstitial space (Cheville 1994). This process triggers the formation of antibodies against sperm antigens, producing a systemic immune response (Oliveira 2007).

A low frequency of fibroplasia and neovascularization were also found, which indicated insufficient time for tissue repair (initial phase of tissue repair) in bovine at 45 days post-application of the calcium chloride. This finding may be supported by lower frequency of mononuclear inflammatory cells, which are responsible to synthesize local growth factors, as VEGF and FGF, to induce the cicatritial process (Cheville 1994), making unnecessary the subsequent histology to elucidate the injury evolution. This action may be associated with the 
presence of DMSO in the solution. Furthermore, Cheville (1994) affirmed that fibroplasia and neovascularization are delayed when tissue oxygenation is poor, which occurred in injured tissue.

Testicular microscopic observations revealed that calcium chloride induced severe cell hypoxic injury and extensive tissue necrosis. Cellular necrosis ranged in intensity from pronounced to moderate at calcium chloride concentrations of $20 \%$ and $30 \%$, particularly in the medial region of the testes. In animals administered calcium chloride at $40 \%$, necrosis was observed in all regions, but with a greater intensity in the middle third. The application site of calcium chloride should be better evaluated in future studies, since the extent of necrosis was greater at the medial portion of testis (injection site).

Chemical sterilization with calcium chloride is a simple and low-cost method, which does not require surgery and is easy to use in farms. Furthermore, we found that $40 \%$ calcium chloride was more efficient in impairing spermatogenesis when injected into the medial region of the testes of bulls, and the joint use of calcium chloride and DMSO reduced the level of pain and retarded the progression of parenchymal testicular fibrosis.

Conflicts of interest.- We confirm that we have no conflicts of interest.

Acknowledgements.- The study was supported by University of Franca (Unifran), Franca, SP, Brazil and JA Saúde Animal, Patrocínio Paulista, SP, Brazil.

\section{REFERENCES}

Almeida K.B., Silveira A.C. \& Oliveira V.A. 2010. Orquiectomia em bovinos. Encicl. Biosfera 6:1-14.

Alves G.E.S., Santos J.A.P.M., Tannus R.J. \& Jannuzzi C.M.P. 2007. Aspectos fisiológicos e econômicos da castração em animais de produção e companhia: verdades e crendices. Revta CFMV 1:67-75.

Andrade S.F. 2002. Manual de Terapêutica Veterinária. 2aㅡ ed. Roca, São Paulo. 936p.

Andrade-Neto O.A.S., Gasperin B.G., Rovani M.T., Ilha G.F., Nóbrega Junior J.E., Mondadori R.G., Gonçalves P.B. \& Antoniazzi A.Q. 2014. Intratesticular hypertonic sodium chloride solution treatment as a method of chemical castration in cattle. Theriogenology 82(7):1007-1011e1. <http://dx.doi. org/10.1016/j.theriogenology.2014.07.020><PMid:25149022>

Angelo T.A.S., Pitombo R.S., Rodrigues V.C., Costa E.C.P. \& Cabral Neto O. 2010. Crescimento de bovinos Nelore, F1 Sindi x Nelores e bubalinos mediterrâneos castrados e inteiros. Revta Ciênc. Vida 30:1-10.

Aydos K., Soygür T., Küpeli B., Unsal A., Tolunay O., Erdem E., Güven C. \& Küpeli S. 1998. Testicular effects of vasectomy in rats: an ultrastructural and immunohistochemical study. Urology 51(6):1051-1056. <http://dx.doi. org/10.1016/S0090-4295(98)00100-9><PMid:9609654>

Bailey T.L., Hudson R.S., Powe T.A., Riddell M.G., Wolfe D.F. \& Carson R.L. 1998. Caliper and ultrasonographic measurements of bovine testicles and a mathematical formula for determining testicular volume and weight in vivo. Theriogenology 49(3):581-594.<http://dx.doi.org/10.1016/S0093691X(98)00009-0><PMid:10732037>

Barnett B.D. 1985. Chemical vasectomy of domestic dogs in the Galapagos islands. Theriogenology 23(3):499-509. <http://dx.doi.org/10.1016/0093691X(85)90022-6><PMid:16726020>

Canpolat I., Bulut S., Gunay C., Eroksuz H. \& Gur S. 2006. An evaluation of the outcome of bull castration by intra-testicular injection of ethanol and calcium chloride. Rev. Med. Vet.,Toulouse, 157:420-425.
Carvalho K.A. 2010. Direito Constitucional. 16aㅡ ed. Del Rey, Belo Horizonte.

Cavalieri J., Wang M. \& Johnson L. 2015. Chemical sterilisation of Bos indicus bull calves following intratesticular injection of zinc acetate: Effects on semen quality and testicular changes. Anim. Reprod. Sci. 156:23-33. <http://dx.doi.org/10.1016/j.anireprosci.2015.02.004><PMid:25752498>

Cheville N.F. 1994. Introdução à Patologia Veterinária. Manole, São Paulo. 482p.

Fahim M.S., Wang M., Sutcu M.F., Fahim Z. \& Youngquist R.S. 1993. Sterilization of dogs with intra-epididymal injection of zinc arginine. Contraception 47(1):107-122. <http://dx.doi.org/10.1016/0010-7824(93)90113-L> <PMid:8435998>

Goldsmith A., Edelman D.A. \& Zatuchni G.I. 1985. Transcutaneous male sterilization. Res. Fertil. Regul. 3(4):1-8. <PMid:12179626>

Guimarães S.B., Kimura O.S. \& Vasconcelos P.R.L. 2010. Dimethylsulfoxide attenuates ischemia-reperfusion injury in rat tests. Acta Cir. Bras. 25(4):357-361. <http://dx.doi.org/10.1590/S0102-86502010000400011> $<$ PMid:20676495>

Habenicht U.F., Schneider M.R. \& Etreby M.F. 1990. Induction of chemical castration in male rats by a new long-acting LHRH-antagonist. Prostate 17(1):69-83. <http://dx.doi.org/10.1002/pros.2990170108><PMid:2201007>

Hafez E.S.S.E. \& Hafez B. 2004. Reprodução Animal. 7ª ed. Manole, Barueri. 513p.

Hedlund C.S. 2005. Cirurgia do sistema reprodutor e genital, p.610-622. In: Fossun T.W. (Ed.), Cirurgia de Pequenos Animais. Roca, São Paulo.

Immegart H.M. \& Threlfall W.R. 2000. Evaluation of intratesticular injection of glycerol for nonsurgical sterelization of dogs. J. Am. Vet. Med. Assoc. 61(5):544-549. <PMid:10803650>

Jana K. \& Samanta P.K. 2006. Evaluation of single intratesticular injection of calcium chloride for nonsurgical sterilization in adult albino rats. Contraception 73(3):289-300. <http://dx.doi.org/10.1016/j.contraception.2005.07.011> <PMid:16472573>

Jana K. \& Samanta P.K. 2007. Sterilization of male stray dogs with a single intratesticular injection of calcium chloride: a dose-dependent study. Contraception 75(5):390-400. <http://dx.doi.org/10.1016/j. contraception.2007.01.022 > <PMid:17434022>

Jana K. \& Samanta P.K. 2011. Clinical evaluation of non-surgical sterilization of male cats with single intra-testicular injection of calcium chloride. BMC Vet. Res. 7(1):39. <http://dx.doi.org/10.1186/1746-6148-7-39> <PMid:21774835>

Jana K., Samanta P.K. \& Ghosh D. 2005. Evaluation of single intratesticular injection of calcium chloride for nonsurgical sterilization of male Black Bengal goats (Capra hircus): a dose-dependent study. Anim. Reprod. Sci. 86(1/2):89-108. <http://dx.doi.org/10.1016/j.anireprosci.2004.05.021> <PMid:15721661>

Kar A.B., Kamboj V.P. \& Goswami A. 1965. Sterilization of male rhesus monkeys by iron salts. J. Reprod. Fertil. 9(1):115-117.<http://dx.doi.org/10.1530/ jrf.0.0090115><PMid:14257713>

Koger L.M. 1977. Calcium chloride, practical necrotising agent. Proceedings of Annual Meeting of the American Society of Animal Science, University of Wisconsin, Madison, WI, USA, p.118-119. (Abstract)

Koger L.M. 1978. Calcium chloride castration. Modern Vet. Pract. 59(2):119121. <PMid:564449>

Lewis R.W.\& Garcia R.R. 1984. The results of epididymal ablation by sclerosing agents in the nonhuman primate. Fertil. Steril. 41(3):465-469. <http:// dx.doi.org/10.1016/S0015-0282(16)47729-0><PMid:6698239>

Luna L.G. 1968. Manual of histological staining methods of the Armed Forces Institute of Pathology. McGraw-Hill, New York. 258p.

Martins L.T., Gonçalves M.C., Tavares K.C.S., Gaudêncio S., Santos Neto P.C., Dias A.L.G., Gava A., Saito M.E., Oliveira C.A., Mezzalira A. \& Vieira A.D. 2011. Castration methods do not affect weight gain and have diverse impacts on 
the welfare of water buffalo males. Livest. Sci. 140(1/3):171-176. <http:// dx.doi.org/10.1016/j.livsci.2011.03.026>

McLachlan R.I. 2000. The endocrine control of spermatogenesis. Bailliere Clin. Endocr. Metabol. 14(3):345-362. <PMid:11097780>

Mitra B. \& Samanta P.K. 2000. Testicular degeneration of scrub bulls by calcium chloride. Indian J. Vet. Surg. 21:37-38.

Mitra B. \& Samanta P.K. 2001. Changes in testosterone level in scrub bulls by intratesticular administration of calcium chloride. Indian J. Vet. Med. 21:98.

Muller P.M., Oliveira E.C.S., Silva F.L.M., Silva L.G., Brito L.T. \& Pereira L.C. 2009a. Castração química de cães machos: mito ou realidade? Anais da IX Jornada de Ensino, Pesquisa e Extensão da UFRPE, Recife, Brasil, p.1-3. (Resumo)

Muller P.M., Oliveira E.C.S., Silva F.L.M., Silva L.G., Brito L.T. \& Teixeira M.J.C.D.S. 2009b. Avaliação das características da próstata de cães submetidos a injeção intratesticular de gluconato de zinco. Anais da IX Jornada de Ensino, Pesquisa e Extensão da UFRPE, Recife, Brasil, p.1-2. (Resumo)

Muller P.M., Oliveira E.C.S., Silva F.L.M., Silva L.G., Carvalho D.S., Fagundes A.K.F. \& Mendes S.K. 2010. Castração química de cães machos - aspectos clínicos, bioquímicos, reprodutivos e comportamentais. Anais da IX Jornada de Ensino, Pesquisa e Extensão da UFRPE, Recife, Brasil, p.1-3. (Resumo)

Munson L., Chassy L.M. \& Asa C. 2004. Efficacy, safety and reversibility of bisdiamine as male contraceptive in cats. Theriogenology 62(1/2):81-92. <http://dx.doi.org/10.1016/j.theriogenology.2003.07.026><PMid:15159103>

Navarrete Y.M.G. 1997. Chemical castration in male dogs with clorhexidine digluconate at $3 \%$ in DMSO (dymethil sulfoxide) at 50\%. Thesis, Concepcion Universidad de Chile.

Neilson J.C., Eckstein R. \& Hart B. 1997. Effects on castration on problem behaviors in male dogs with reference to age and duration of behavior. J. Am. Vet. Med. Assoc. 211(2):180-182. <PMid:9227747>

Nyland T.G. \& Mattoon J.S. 2001. Veterinary Diagnostic Ultrasound. 2nd ed. Saunders, Philadelphia. 461p.

Oliveira E.C.S. 2007. Esterilização de cães com injeção intratesticular de solução à base de zinco. Tese de Doutorado, Universidade Federal de Minas Gerais, Belo Horizonte, MG. 90p.

Oliveira F.C., Ferreira C.E.R., Haas C.S., Oliveira L.G., Mondadori R.G., Schneider A., Rovani M.T., Gonçalves P.B.D., Vieira A.D., Gasperin B.G. \& Lucia Junior T. 2017. Chemical castration in cattle with intratesticular injection of sodium chloride: effects on stress and inflammatory markers. Theriogenology 90:114-119.<http://dx.doi.org/10.1016/j.theriogenology.2016.12.001> $<$ PMid:28166957>

Pate F.M., Johnson A.D. \& Miller W.J. 1970. Testicular changes in calves following injection with cadmium chloride. J. Anim. Sci. 31(3):559-564. <http://dx.doi.org/10.2527/jas1970.313559x><PMid:5520346>

Pearson H., Arthur G.H., Rosevink B. \& Kakati B. 1980. Ligation and sclerosis of the epididymis in the bull. Vet. Rec. 107(12):285-287. <http://dx.doi. org/10.1136/vr.107.12.285><PMid:7210423>

Penasso P. 2005. Repercussões clínicas e histopatológicas do dimetilsulfóxido em Gerbil submetidos à isquemia cerebral experimental. Dissertação de Mestrado, Universidade de Franca, Franca, SP.

Pineda M.H. \& Dooley M.P. 1984. Surgical and chemical vasectomy in the cat. Am. J. Vet. Res. 45(2):291-300. <PMid:6711952>

Pineda M.H., Reimers T.J., Faulkner L.C., Hopwood M.L. \& Seidel Junior G.E. 1977. Azoospermia in dogs induced by injection of sclerosing agents into the caudae of the epididymides. Am. J. Vet. Res. 38(6):831-838. <PMid:560154>

Plant J.W., Seaman J.T. \& Jakovljevic D. 1979. Non-surgical sterilization of rams using a sclerosing agent. Austr. Vet. J. 55(6):263-264. <http://dx.doi. $\operatorname{org} / 10.1111 / \mathrm{j} .1751-0813.1979 . t b 14706 . x>$
Prado C.S., Pádua J.T., Corrêa M.P.C., Ferraz J.B.S., Miyagi E.S. \& Resende L.S. 2004. Comparação de diferentes métodos de avaliação da área de olho de lombo e cobertura de gordura em bovinos de corte. Ciênc. Anim. Bras. 5:141-149.

Rodrigues V.C., Andrade I.F., Freitas R.T., Bressan M.C. \& Teixeira J.C. 2003. Rendimentos do abate e carcaça de bovinos e bubalinos castrados e inteiros. Revta Bras. Zootec. 32(3):663-671. <http://dx.doi.org/10.1590/ S1516-35982003000300018>

Santamaría L., Martín R., Codesal J., Ramírez R. \& Paniagua R. 1995. Immunohistochemical quantitative study of the peritubular lamina propria after induction of testicular atrophy induced by epinephrine. Int. J. Androl. 18(6):295-306. <http://dx.doi.org/10.1111/j.1365-2605.1995.tb00565. $\mathrm{x}><$ PMid:8719845>

Santos A.P. 2005. Desempenho, características da carcaça e da carne de bovinos de diferentes sexos e idades, terminados em confinamento. Dissertação de Mestrado, Universidade Federal de Santa Maria, RS. 133p.

Santos J.A. 1978. Patologia Geral dos Animais Domésticos: mamíferos e aves. $2^{\mathrm{a}}$ ed. Interamericana, Rio de Janeiro. 490p.

Santos J.A. 1986. Patologia Especial dos Animais Domésticos: mamíferos e aves. $2^{\underline{a}}$ ed. Guanabara, Rio de Janeiro. 661p.

Setchell B.P., Maddocks S. \& Brooks D.E. 1994. Anatomy, vasculature, innervations and fluids of the male reproductive tract, p.1063-1175. In: Knobil E. \& Neil J.D. (Eds), The Physiology of Reproduction, 2nd ed. Raven Press, New York.

Sheehan D.C. \& Hrapchak B.B. 1980. Theory and Practice of Histotechnology. Battelle Press, Columbus, Ohio, p.153-154.

Silva L.A.F., Costa A.C., Soares L.K., Borges N.C., Ferreira J.L. \& Cardoso L.L. 2009. Orquiectomia em bovinos empregando a braçadeira de nylon na homeostasia preventiva: efeito da estação do ano, método de contenção e técnica cirúrgica. Ciênc. Anim. Bras. 10:261-270.

Silva N.L., Silva E.A.D.A. \& Paes J.M.V. 2006. Desempenho e eficiência do imobilizador retal em bovinos submetidos a dois métodos de castração em condições de pastagem. Anais da V Jornada Científica da FAZU, Faculdades Associadas de Uberaba, Uberaba, Brasil, p.329-333.

Soto F.R.M., Viana W.G., Sousa A.J., Pinheiro S.R., Mucciolo G.B., Hosomi F.I.M., Azevedo S.S. \& Dias R.A. 2007. Evaluation of zinc gluconate, either associated or not to dimethyl sulfoxide, as contraceptive method for male dogs. Anim. Reprod. 4(3/4):119-124.

Thomson R.G. 1983. Patologia geral veterinária, p.144-242. In: Ibid. (Ed.), Inflamação e Reparação. Guanabara Koogan, Rio de Janeiro.

Turner A.S. \& McIlwaith C.W. 2002. Técnicas Cirúrgicas em Animais de Grande Porte. Roca, São Paulo. 354p.

Vanderstichel R., Forzán M.J., Pérez G.E., Serpell J.A. \& Garde E. 2015. Changes in blood testosterone concentrations after surgical and chemical sterilization of male free-roaming dogs in southern Chile. Theriogenology 83(6):1021-1027.<http://dx.doi.org/10.1016/j.theriogenology.2014.12.001> $<$ PMid:25557187>

Vannucchi C.I., Angrimani D.S.R., Eyherabide A.R., Mazzei C.P., Lucio C.F., Maiorka P.C., Silva L.C.G. \& Nichi M. 2015. Effects of intratesticular administration of zinc gluconate and dimethyl sulfoxide on clinical, endocrinological, and reproductive parameters in dogs. Theriogenology 84(7):1103-1110.<http:// dx.doi.org/10.1016/j.theriogenology.2015.06.005> <PMid:26174036>

Wang M. 2002. Neutersol: intratesticular injection induces sterility in dogs. Proc. International Symposium on Nonsurgical Methods for Pet Population Control, Alliance for Contraception in Cats and Dogs, Pine Mountain, GA, USA, p.62-65. (Abstract)

Wong C.M. 2001. Chemical castration: Oregon's innovative approach to sex offender rehabilitation, or unconstitutional punishment? Oregon Law Rev. 80(1):267-301. 